\title{
Gardening for health: a regular dose of gardening
}

\author{
Author: Richard Thompson ${ }^{\mathrm{A}}$
}

There is increasing evidence that exposure to plants and green space, and particularly to gardening, is beneficial to mental and physical health, and so could reduce the pressure on NHS services. Health professionals should therefore encourage their patients to make use of green space and to work in gardens, and should pressure local authorities to increase open spaces and the number of trees, thus also helping to counteract air pollution and climate change.

There is anxiety that the NHS cannot cope now and in the future with the health needs of an increasing and ageing population. It is also realised that pharmaceutical drugs, transformative though they have been, are increasingly expensive and are not always as effective as they appear in the results of early, enthusiastically reported, clinical trials. Drugs are also prescribed at the cost of side effects, which are a leading cause of admissions to hospital, particularly for the elderly, who are poorly represented in trials.

Health depends on a range of social, economic and environmental factors, as is emphasised by the shaming disparity between the length of life in different areas of the country. In addition to improving the information given to patients and health professionals on the true efficacy of drugs and on their risks, and thus empowering choices for patients, there are opportunities to treat some physical and mental conditions with alternative or complementary therapies, and to encourage changes in lifestyle. Such treatments could reduce the workload and financial pressure on the NHS, particularly in primary care, but they clearly must only be recommended by health professionals if there is good evidence that they are effective; many are without merit. Ten million of the UK population are defined as disabled, among them 6.9 million of working age. Can we do better for these people without using drugs?

\section{Green care}

One group of holistic therapies that aim to treat the whole person and has been well researched through surveys and randomised trials is so-called green care, or therapy by exposure to plants and gardening. ${ }^{2,3}$ Several trials have revealed the beneficial effects on mood and mental health of simply observing nature, or even images of natural scenes. In a Japanese study, viewing plants altered EEG recordings and reduced stress, fear, anger and sadness, as well as reducing blood pressure, pulse rate and

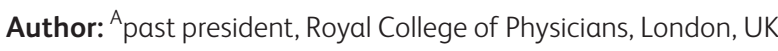

muscle tension. ${ }^{4}$ Another Japanese study simply found that it more beneficial physiologically to view a green hedge rather than a concrete fence. ${ }^{5}$ In a pioneering randomised study by the environmental psychologist Roger Ulrich, ${ }^{6}$ views of plants and trees from post-operative wards improved the mood of patients, and reduced analgesic use, surgical complications and length of stay. Similar beneficial results have been found for patients undergoing dental treatment, ${ }^{7}$ and viewing natural scenes together with natural sounds improved the experience of bronchoscopy. ${ }^{8}$ Another carefully controlled study showed that viewing sculpture gardens without any greenery through the windows of an oncology ward caused a negative reaction in many patients. ${ }^{9}$ Even randomly exposing post operative patients to pictures of countryside on the walls of their rooms can reduce pain and anxiety, while, perhaps not surprising to everyone, abstract images increased anxiety. ${ }^{10,11}$ It would be interesting to study the mental effects of visiting art galleries! Paintings on the walls of a Swedish psychiatric hospital were often vandalised, but only if they were of abstract images, not if they were landscapes. ${ }^{12}$ The charity MIND compared short walks through a garden with walks in a shopping complex, and showed that the former improved mental health, whereas the latter made it worse. ${ }^{13}$ In a prison in Michigan, residents who had a view of the countryside from their cells used the prison medical services less than those with an internal courtyard view. ${ }^{14}$

In another randomised experiment, when post-operative patients were exposed to eight different species of indoor plants, both pain and length of stay were once again reduced and patients' satisfaction with their hospital rooms was improved. ${ }^{15}$ Exposing pictures of flowers in the dictator game, which is an economic game that questions whether individuals are solely driven by self interest, can change the decisions made by the players. ${ }^{16}$ In another study, putting plants in a computer room improved productivity and lowered blood pressure. ${ }^{17}$ Indoor gardening has been used to treat patients with mental health problems. ${ }^{18}$ It is not only the appearance of plants that is beneficial: their leaves remove toxins, dust and microorganisms from the air and they also produce the so-called negative ions from their leaves. The overall evidence that charged ions affect mood is, however, unconvincing, ${ }^{19}$ despite advertisements strongly recommending their benefits.

Many studies in the UK and other countries concur that higher proportions of green space, especially biodiverse habitats, ${ }^{20}$ are associated with less depression, anxiety and stress, even after controlling for potential confounding factors such as deprivation. ${ }^{20-22}$ In Japan, green space has been linked with increased longevity. ${ }^{23}$ Exposure to green space seems to reduce 
health inequalities related to deprivation, ${ }^{24}$ but associations are not proof of an hypothesis and a few studies have disagreed. ${ }^{25,26}$ In reality, studies such as these suffer from embedded residual confounding correlations between green space and higher income, better housing, and healthier lifestyles (such as less smoking), which can be difficult to disentangle. Interestingly, the benefit of green space may not be simply related to physical activity, ${ }^{27,28}$ but might rely more on improved social interaction. ${ }^{29}$

\section{Gardens}

Therapeutic gardens have been used in hospitals for thousands of years, and were strongly supported by Florence Nightingale; they improve the surroundings for patients, visitors and staff. Ulrich ${ }^{11}$ has emphasised their beneficial effects on stress, especially if the spaces support biodiversity, with increased satisfaction reported by those who use them.

A small central garden between buildings at St Thomas' Hospital was created for the millennium; another at St George's Hospital was successfully commissioned by Harold Lambert FRCP. Gardens that are attached to hospices, such as Maggie's cancer centres, ${ }^{30}$ and care homes are now widespread and provide that important view from the rooms and an area to visit. Recently, impressive gardens for wheelchair users and those confined to beds have been designed around spinal injury units; these are known as Horatio's gardens and have been set up in memory of Horatio Chapple, who died in an accident in the Arctic. ${ }^{31}$ They can include facilities for therapy and training in gardening skills.

Gardens around prisons have a long history of improving the lives of the prisoners and offering training towards employment in the horticulture industry. At the urban prison in Wandsworth, a collaboration with The Conservation Foundation has seen green areas introduced into the prison and an exercise yard dug up to make way for a vegetable garden where produce can be grown. ${ }^{32}$ In the First World War, British prisoners in the civilian internment camp at Ruhleben in Germany were sent seeds and plants by the Royal Horticultural Society in London to help them to develop a successful garden. ${ }^{33}$

A recent survey by Mintel for the charity Thrive, ${ }^{34}$ which enables social and therapeutic horticulture, showed that among people with disabilities, a quarter listed gardening as a hobby. Two-thirds of the respondents owned a garden and $87 \%$ had access to a garden that they thought was beneficial to their health. Surveys in the general population have given similar results, ${ }^{35}$ with a large majority believing that gardens were beneficial to health. Numbers of visitors to garden centres and private gardens, such as those in the National Garden Scheme or run by the National Trust, are increasing. Gardening has been associated with a lower prevalence of dementia and with positive health effects in several countries, ${ }^{36,37}$ and economic benefits have been shown, for instance, for mental health services. ${ }^{38}$

In northern Europe, Green Care Farms have proved popular and have grown in number so that there are now hundreds of such facilities in Norway and in the Netherlands. Patients who have impaired mental health, learning disabilities or drug dependency, as well as older people, are referred for a period of work in functioning farms, often involving animals. ${ }^{39}$ In England, the University of Essex has set up the National Care Farms network. By 2012, the network included 180 farms, which were visited by 3000 patients a week; ${ }^{40}$ their positive benefits have been independently reviewed. ${ }^{41}$ The charity Thrive has identified 800 therapeutic horticulture projects across England and Wales.

\section{The effects of gardening on body and mind}

Why does gardening seem to be so beneficial to health? It combines physical activity with social interaction and exposure to nature and sunlight. Sunlight lowers blood pressure as well as increasing vitamin D levels in the summer, ${ }^{42}$ and the fruit and vegetables that are produced have a positive impact on the diet. Working in the garden restores dexterity and strength, and the aerobic exercise that is involved can easily use the same number of calories as might be expended in a gym. Digging, raking and mowing are particularly calorie intense; ${ }^{43}$ there is a gym outside many a window. The social interaction provided by communal and therapeutic garden projects for those with learning disabilities and poor mental health can counteract social isolation. Furthermore, it has also been reported that the social benefits of such projects can delay the symptoms of dementia ${ }^{44}$ (an effect that might be partly due to the beneficial effects of exercise). Patients who are recovering from myocardial infarction or stroke find that exercise in a garden, using constraint therapy of a paretic limb, for example, ${ }^{45}$ is more effective, enjoyable and sustainable than therapy in formal exercise settings. For some patients, gardening can even lead to employment. There are also successful schemes that involve volunteers to help older people who cannot manage their gardens, with both the volunteer and the owner benefitting from the social interaction and from the produce and a shared interest.

Intelligent Health points out that the pandemic of physical inactivity is the fourth leading cause of premature death, and contributes to preventable physical and mental disorders. ${ }^{46}$ The Department of Health calculates that an increase of only $10 \%$ in average exercise by adults would postpone 6000 deaths and save $€ 500$ million annually. ${ }^{47}$ Regular moderate intensity exercise may reduce the risk of dementia, ${ }^{48}$ mental health problems, cardiovascular disease, diabetes, and cancer of the breast and colon, and in an Australian study, gardening was found to be more effective than walking, education or maintaining alcohol intake at moderate levels in protecting against dementia. ${ }^{44}$ It enhances self esteem and alters the EEG. ${ }^{49}$ Similarly, moderate exercise in leisure time is associated with increased longevity, regardless of weight, ${ }^{50-52}$ particularly if combined with exposure to natural scenes, ${ }^{53}$ although some studies have suggested that exercise declines with reduced cognition; a reverse causation bias.

Thankfully, high intensity exercise is not needed to obtain these benefits, ${ }^{51,52}$ which is perhaps as well given that the uptake of cycling-and gym-based exercise is poor in the older population, and that these activities can be expensive. Gardening or simply walking through green spaces could therefore be important in preventing and treating ill health. The Five Year Forward Plan for the $\mathrm{NHS}^{54}$ emphasises the potential importance of prevention in reducing the mounting pressure on the NHS and on social services. There are 152,000 strokes annually and a total of 1.2 million stroke survivors in the UK. ${ }^{55}$ Also in the UK, a quarter of a million patients are admitted to psychiatric hospitals each year and dementia is predicted to affect a million people by 2025.

Few complementary therapies have been convincingly shown to be effective, but gardening and nature, which are alternative therapies, offer a proven, cheap and nearly universally available means to improve the nation's health. Although there is evidence that knitting can also help! ${ }^{56}$ 


\section{The green environment}

The 2016 RCP report on pollution ${ }^{57}$ underlined the deleterious effects of air pollution on respiratory and cardiovascular health globally, with an estimated 8000 premature deaths a year in the UK alone being linked to this issue. The House of Lords has reported specifically on the poor air quality in London. ${ }^{58}$ Poor air quality can be associated with higher mortality in acute medical wards. ${ }^{59}$ Not only larger forests ${ }^{60}$ but also urban forests ${ }^{47}$ can offset this, as can plants in buildings, gardens, parks, and roadways. Trees, for instance, remove large quantities of toxins and particulates through their leaves, ${ }^{61}$ transmitting toxins to the soil where microorganisms metabolise them, or trapping them in hairs on leaves that later fall. ${ }^{61}$ Roadside trees reduce the indoor concentration of particulates. ${ }^{62}$ Although evergreen trees have smaller leaf areas than their deciduous cousins, they are more effective in the winter months. Trees themselves do emit varying amounts of volatile compounds, ${ }^{63}$ but overall they reduce the levels of pollutants close to roads. ${ }^{64-66}$ For instance, a single maple tree can remove $48 \mathrm{lb}(22 \mathrm{~kg})$ of particulates and $100 \mathrm{lb}(45 \mathrm{~kg})$ of carbon each year, as well as toxic metals, nitrogen oxides and sulphur dioxide. The link between residence close to roads and dementia and other problems ${ }^{67}$ could be due to exposure to the many pollutants emitted by vehicles, such as nitrogen oxides, carbon dioxide, ozone, metals, organic compounds and differently sized particulates.

Trees, hedges, and other plants counter climate change by trapping carbon and emitting oxygen; and worldwide, forests may offset a quarter of man-made carbon dioxide. They also improve the environment by reducing noise, heat, glare, wind, water runoff, erosion and dust. Cooling from shading and the evaporation of water from leaves can reduce the need for air conditioning in buildings, and cooling also reduces the formation of some pollutants, such as ozone. Even lawns and turf are helpful, ${ }^{68,69}$ also trapping pollutants and passing them on to soil microorganisms, in addition to providing recreational space for exercise. Plants may also help to solve the problem of polluted soils in industrial areas. Architects are reluctant to preserve old trees or add them to their developments, and so trees must be protected or included in planning consent conditions, and later properly maintained.

\section{What can health professionals do?}

Health professionals should encourage their patients not to see danger in exercise in the garden, green spaces, parks and the countryside. Instead, they should emphasise the potential benefits to patients' health, ${ }^{70}$ such as improvements in strength, balance and dexterity. When appropriate, patients can be referred to local community and therapeutic gardening projects, where occupational therapists trained in horticulture help them to manage and treat their medical issues. ${ }^{71}$ This is part of what has become known as social prescribing ${ }^{72}$ or community referral, which has the potential to improve the physical and mental health of the population by preventing illness or by ameliorating the effects of established disability. Gardens can also help to improve parity between the treatments for mental and physical disabilities.

The particular benefit of gardening to veterans of the armed services has been fully reviewed. ${ }^{73}$ Both mental conditions, such a post traumatic stress disorder, and the effects of physical injuries can be improved, ${ }^{74}$ and there are opportunities to train for a new career in the expanding horticulture industry. Health professionals should encourage the development of gardens in hospitals, hospices, schools ${ }^{75}$ and prisons. They should try to influence the design of new health service buildings by insisting that there are views of outside nature from every patient and staff room, and by placing internal plants in atria, communal areas, surgeries, clinics and staff rooms, even if they are misguidedly banned from wards. Even window boxes and balconies can be used. Health professionals should also encourage the teaching of the skills and benefits of gardening in schools. ${ }^{75}$

In addition, health professionals should encourage local authorities to plant more trees; the Greater London Authority alone plans to plant two million more trees by $2025 .{ }^{76}$ Green spaces, parks, gardens and allotments will improve the environment, ${ }^{77-79}$ particularly where gardens are in short supply, as in deprived urban areas. Despite the apparent density of buildings in our towns, they do contain gardens and green areas, with an average of one fifth of the land in UK towns being given over to green space. Even in the most crowded cities, such as New York and Singapore, roof gardens, green walls and hanging containers are popular. A well-kept local environment improves local pride and can reduce crime and social isolation. Urban planners must be convinced of the importance of including green space, ${ }^{79,80}$ as they are in Holland. ${ }^{81}$

I endorse Buck's proposal ${ }^{2}$ that gardens and gardening should be incorporated in NHS England's programmes for improving public health, and hope that health professionals will be in the vanguard of the campaign. They should also support the longstanding charity Fields in Trust (previously the National Playing Fields Association), which campaigns to preserve and increase public green spaces.

\section{Conflicts of interest}

The author is a trustee of the National Garden Scheme, and past trustee, now patron, of the charity Thrive. He is a member of the Royal Horticulture Society's Health and Horticulture Forum, and he gardens in London.

\section{References}

1 Marmot M, Goldblatt P, Allen ] et al. Fairer society, healthy lives (the Marmot review). Institute of Health Equity, 2017. www. instituteofhealthequity.org/resources-reports/fair-society-healthylives-the-marmot-review [Accessed 29 March 2018].

2 Buck D. Gardens and health; implications for policy and practice. King's Fund, 2016. www.kingsfund.org.uk/publications/gardensand-health [Accessed 29 March 2018].

3 Sempik J, Aldridge J, Becker S. Social and therapeutic horticulture: evidence and messages from research. Loughborough: Centre for Child and Family Research, Loughborough University, 2003. https://dspace.lboro.ac.uk/dspace-jspui/bitstream/2134/2928/1/ Evidence6.pdf [Accessed 29 March 2018].

4 Nakamura R, Fujii E. Studies of the characteristics of the electroencephalogram when observing potted plants. Techn Bull Fac Hort Chiba Univ 1990;43:177-83.

5 Nakamura R, Fujii E. A comparative study of the characteristics of the electroencephalogram when observing a hedge and a concrete block fence. J Jap Inst Landscape Architects 1992;55:139-44.

6 Ulrich RS. View though a window may influence recovery from surgery. Science 1984;224:420-1.

7 Heerwagen J. The psychological aspects of windows and window design. In: Anthony KH, Choi J, Orland B (eds), Proceedings of the 21st Annual Conference of the Environmental Design Research Association. St. Paul, MN: EDRA, 1990;269-80. 
8 Diette GB, Lechtzin N, Haponik E, Devrotes A, Rubin HR. Distraction therapy with nature sights and sounds reduces pain during flexible bronchoscopy. Chest 2003;123:941-8.

9 Hefferman ML, Morstatt M, Saltzman K, Strunc L. A room with a view art survey: the bird garden at Duke University Hospital. Durham, NC: Cultural Services Program and Management Fellows Program, Duke University Medical Center, 1995.

10 Ulrich RS, Lundén O, Eltinge JL. Effects of exposure to nature and abstract pictures on patients recovering from heart surgery. Psychphysiol 1993;Suppl 1:7.

11 Ulrich RS. Health benefits of gardens in hospitals. Plants for People Conference, 2002.

12 Ulrich RS. Effects of interior design on wellness: theory and recent scientific research. J Health Care Inter Des 1991:3:97-109.

13 Peacock J, Hine R, Pretty J. The mental health benefits of green exercise activities and green care. MIND, 2007. https://psyk-info. regionsyddanmark.dk/dwn109161.pdf [Accessed 29 March 2018].

14 Moore EO. A prison environment's effect on health care service demands. J Env Systems 1981-2;11:17-34.

15 Park SH, Mattson RH. Ornamental indoor plants in hospital rooms enhanced health outcomes of patients recovering from surgery. J Altern Complement Med 2009;15:975-80.

16 Raihani NJ, Bshary R. A positive effect of flowers rather than eye images in a large-scale, cross-cultural dictator game. Proc Biol SC 2012;279:3556-64.

17 Lohr VI, Pearson-Mims CH, Goodwin GK. Interior plants may improve worker productivity and reduce stress in a windowless environment. J Environ Hort 1996;14:97-100.

18 Spring JA, Baker M, Dauya L et al. Gardening with Huntingdon's disease clients - creating a programme of winter activities. Disabil Rehab 2011;33:159-64.

19 Perez V, Alexander DD, Bailey WH. Air ions and mood outcomes: a review and meta-analysis. BMC Psychiatry 2013;13:29.

20 Fuller RA, Irvine KN, Devine-Wright P, Warren PH, Gaston KJ. Psychological benefits of greenspace increase with biodiversity. Biol Letters 2007:3:390-4

21 Beyer KMM, Kaltenbach A, Szabo A et al. Exposure to neighbourhood green space and mental health: evidence from the survey of the health of Wisconsin. Int I Environ Res Public Health 2014;11:3453-72.

22 Maas J, Verheij RA, de Vries S et al. Morbidity is related to a green living environment. J Epidemiol Comm Health 2009:63:967-73.

23 Takano T, Nakamura N, Watanabe M. Urban residential environments and senior citizens' longevity in megacity areas: the importance of walkable green spaces. J Epidemiol Comm Health 2002;56:913-8.

24 Mitchell R, Popham F. Effect of exposure to natural environment on health inequalities: an observational population study. Lancet 2008;372:1655-60.

25 Richardson E, Pearce J, Mitchell K, Day P, Kingham S. The association between green space and cause-specific mortality in urban New Zealand: an ecological analysis of green space utility. BMC Public Health 2010;10:240.

26 Mitchell R, Astell-Burt T, Richardson EA. A comparison of green space indicators for epidemiological research. J Epidemiol Community Health 2011;65:853-8.

27 Maas J, Verheij RA, Spreeuwenberg P, Groenewegen PP. Physical activity as a possible mechanism behind the relationship between green space and health: a multilevel analysis. BMC Public Health 2008:8:206.

28 Richardson EA, Pearce J, Mitchell R, Kingham S. Role of physical activity in the relationship between urban green space and health. Public Health 2013:127:318-24.

29 Maas J, van Dillen SM, Verheij RA, Groenewegen PP. Social contacts as a possible mechanisms behind the relation between green space and health. Health Place 2009;15:586-95.
30 Moberly T. Maggie's cancer centre wins award. BMJ 2017;357:j3113.

31 Leendertz L. Calm and even. The Garden 2017;142:57-60.

32 The Conservation Foundation. Unlocking Nature at HMP Wandsworth, 2017. www.conservationfoundation.co.uk/265 [Accessed 29 March 2018].

33 Royal Horticultural Society. Ruhleben Horticultural Society. www. rhs.org.uk/education-learning/libraries-at-rhs/events-exhibitions/ ruhleben-horticultural-society [Accessed 29 March 2018].

34 Mintel Custom Solutions. Gardening among individuals with a disability. Thrive, 2006. www.thrive.org.uk/files/documents/ ExecSummary.pdf [Accessed 29 March 2018].

35 ComRes. The health benefits of gardening. National Garden Scheme, 2014. www.comresglobal.com/polls/the-national-gardens scheme-benefits-of-gardening-survey/ [Accessed 29 March 2018].

36 Soga M, Gaston KJ, Yamaura Y. Gardening is beneficial for health: a meta-analysis. Prev Med Rep 2017;5: 92-9.

37 Fabrigoule C, Letenneur L, Dartigues JF et al. Social and leisure activities and risk of dementia: a prospective longitudinal study. J Amer Ger Soc 1995:43:485-90.

38 Vardakoulias O. The economic benefits of ecominds. MIND, 2013. www.mind.org.uk/media/338566/The-Economic-Benefits-ofEcominds-report.pdf [Accessed 29 March 2018].

39 KPMG. Green, healthy and productive. Ministry of Economic Affairs, Agriculture and Innovation, The Netherlands, 2012. https://www. cbd.int/financial/values/Netherlands-valuehealth.pdf [Accessed 29 March 2018].

40 Bragg R. Care farming in the UK - key facts and figures. University of Essex, 2013. http://publications.naturalengland.org.uk/ file/5833404847226880 [Accessed 29 March 2018].

41 Hine R, Peacock J, Pretty ]. Care farming in the UK-evidence and opportunities. University of Essex, 2008. www.carefarminguk.org/ sites/carefarminguk.org/files/Care \% 20Farming \% 20in \% 20the \% 20 UK\% 20-\% 20Essex \% 20Uni \% 20Report.pdf [Accessed 29 March 2018].

42 Sowah D, Fan X, Dennett L, Hagtvedt R, Straube S. Vitamin D levels and deficiency with different occupations: a systematic review. BMC Public Health 2017;17:519.

43 Vaz M, Karaolis N, Draper A, Shetty P. A compilation of energy costs of physical activities. Public Health Nutr 2005;8:1153-83.

44 Simons LA, Simons ], McCallum J, Friedlander Y. Lifestyle factors and risk of dementia: Dubbo Study of the elderly. Med J Aust 2006:184:68-70.

45 Wolf SL, Winstein C], Miller JP et al. Effect of constraint-induced movement therapy on upper extremity function 3 to 9 months after stroke. JAMA 2006:296:2095-104.

46 Intelligent Health 2018. www.intelligenthealth.co.uk.

47 Forest Research. Benefits of green infrastructure. Farnham: Forest Research, 2010. www.forestry.gov.uk/pdf/urgp_benefits_of_green infrastructure.pdf/\$FILE/urgp_benefits_of_green_infrastructure. pdf [Accessed 29 March 2018].

48 Larson EB, Wang L, Bowen JD et al. Exercise is associated with reduced risk for incident dementia among persons 65 years of age and older. Ann Intern Med 2006;144:73-81.

49 Vogt T, Schneider S, Abeln V, Anneken V, Strüder HK. Exercise, mood and cognitive performance in intellectual disability neurophysiological approach. Behav Brain Res 2012;226:473-80.

50 Pretty ], Peacock J, Sellens M, Griffin M. The mental and physical health outcomes of green exercise. Int J Environ Health Res 2005;15:319-37.

51 Department of Health. Physical activity guidelines for adults (19-64 years), 2011. www.gov.uk/government/uploads/system/ uploads/attachment_data/file/213740/dh_128145.pdf [Accessed 29 March 2018].

52 Department of Health. Physical activity guidelines for older adults (65+ years), 2011. www.gov.uk/government/uploads/system/ uploads/attachment_data/file/213741/dh_128146.pdf [Accessed 29 March 2018] 
53 Sparling PB, Howard BJ, Dunstan DW, Owen N. Recommendations for physical activity in older adults. BMJ 2015;350:h100.

54 NHS England. NHS five year forward view, 2014. www.england.nhs. uk/five-year-forward-view/ [Accessed 29 March 2018].

55 Stroke Association. State of the nation: stroke statistics, 2017. www.stroke.org.uk/system/files/sotn_2018.pdf [Accessed 29 March 2018].

56 Knit for Peace. The health benefits of knitting, 2017. www. knitforpeace.org.uk/wp-content/uploads/2017/05/The-HealthBenefits-of-Knitting-Preview.pdf [Accessed 29 March 2018].

57 Royal College of Physicians. Every breath we take: the lifelong impact of air pollution. Report of a working party. London: RCP, 2016. www.rcplondon.ac.uk/projects/outputs/every-breath-we-takelifelong-impact-air-pollution [Accessed 29 March 2018].

58 Goddard J, Haves E. Air quality in London. London: House of Lords library briefing, 2017. http://researchbriefings.parliament.uk/ ResearchBriefing/Summary/LLN-2017-0035 [Accessed 29 March 2018]

59 Lyons ], Chotirmall SH, O'Riordan D, Silke B. Air quality impacts mortality in acute medical admissions. Quart J Med 2014;107:347-53.

60 Urban forestry network. Trees improve our air quality. http:// urbanforestrynetwork.org/benefits/air \% 20quality.htm [Accessed 29 March 2018].

61 Smith WH, Staskawicz B]. Removal of atmospheric particles by leaves and twigs of urban trees. Environ Manag 1997;1:317-30.

62 Stewart H, Owen S, Donovan R et al. Trees and sustainable urban air quality. Lancaster: Centre for Ecology and Hydrology, University of Lancaster, 2002.

63 Maher BA, Ahmed IAM, Davison B, Karloukovski V, Clarke R. Impact of roadside tree lines on indoor concentrations of traffic-derived particulate matter. Environ Sci Technol 2013;47:13737-44.

64 Calderón-Garcidueňas L, Villarreal-Rios R. Living close to heavy traffic roads, air pollution, and dementia. Lancet 2017;389:675-7.

65 Chen $\mathrm{H}$, Kwong JC, Copes R et al. Living near major roads and the incidence of dementia, Parkinson's disease, and multiple sclerosis: a population-based cohort study. Lancet 2017;389:718-26.

66 Lovasi GS, Quinn JW, Neckerman KM, Perzanowski MS, Rundle A. Children living in areas with more street trees have lower prevalence of asthma. J Epidemiol Community Health 2008;62:647-9.

67 Nowak DJ, Crane DE, Stevens JC. Air pollution removal by urban trees and shrubs in the United States. Urban Forestry Urban Greening 2006;4:115-23.

68 Beard JB, Green RL. The role of turfgrasses in environmental protection and their benefits to humans. J Environ Qual 1994;23:452-60.

69 Qian Y, Follett RF. Assessing soil carbon sequestration in turfgrass systems using long-term soil testing data. Agron ] 2002;94:930-5.
70 NICE. Mental wellbeing in over 65s: occupational therapy and physical activity interventions. NICE public health guideline 16, 2008. www.nice.org.uk/guidance/ph16 [Accessed 29 March 2018].

71 Legg L, Drummond A, Leonardi-Bee ], et al. Occupational therapy for patients with problems in personal activities of daily living after stroke: systematic review of randomised trials. BMJ 2007;335:922-5.

72 The King's Fund. What is social prescribing? 2017. www.kingsfund. org.uk/publications/social-prescribing [Accessed 29 March 2018].

73 Wise J. Digging for victory. Horticultural therapy with veterans for post-traumatic growth. Karnac Books, 2015.

74 Atkinson J. An evaluation of the Gardening Leave project for ex-military personnel with PTSD and other combat related mental health problems. London: Pears Foundation, 2009. www.researchgate.net/profile/ Jacqueline_Atkinson/publication/265575473_AN_EVALUATION_OF_ THE_GARDENING_LEAVE_PROJECT_FOR_EX-MILITARY_PERSONNEL_ WITH_PTSD_AND_OTHER_COMBAT_RELATED_MENTAL_HEALTH_ PROBLEMS/links/55094b960cf26ff55f852b50.pdf [Accessed 29 March 2018].

75 Royal Horticultural Society. RHS campaign for school gardening. The Garden 2017;142:117.

76 Smith J. The mayor's street tree programme. Final evaluation report: 2008 to 2012. Forestry Commission and Mayor of London, 2012. www.london.gov.uk/sites/default/files/mstp_evaluation_ winter_2012.pdf [Accessed 29 March 2018].

77 McDonald AG, Bealey W], Fowler D et al. Quantifying the effect of urban tree planting on concentrations and depositions of $\mathrm{PM}_{10}$ in two UK conurbations. Atmosph Environ 2007;41:8455-67.

78 Commission for Architecture and the Built Environment (CABE). Green space strategies. A good practice guide. CABE space, 2004. http://webarchive.nationalarchives.gov.uk/20110118095356/ http:/www.cabe.org.uk/files/green-space-strategies.pdf [Accessed 29 March 2018].

79 Smith L, Pratt A. Garden cities, towns and villages. Briefing paper number 06867. House of Commons Library, 2017. http:// researchbriefings.parliament.uk/ResearchBriefing/Summary/ SN06867 [Accessed 29 March 2018].

80 Hartig T, Mitchell R, de Vries S, Frumkin H. Nature and health. Ann Rev Public Health 2014;35:207-28.

81 Maas J, Verheij RA, Groenewegen PP, de Vries S, Spreeuwenberg P. Green space, urbanity, and health: how strong is the relation? J Epidemiol Comm Health 2006;60:587-92.

Address for correspondence: Sir Richard Thompson, 36 Dealtry Road, London SW15 6NL, UK.

Email: richard@rpht.co.uk 